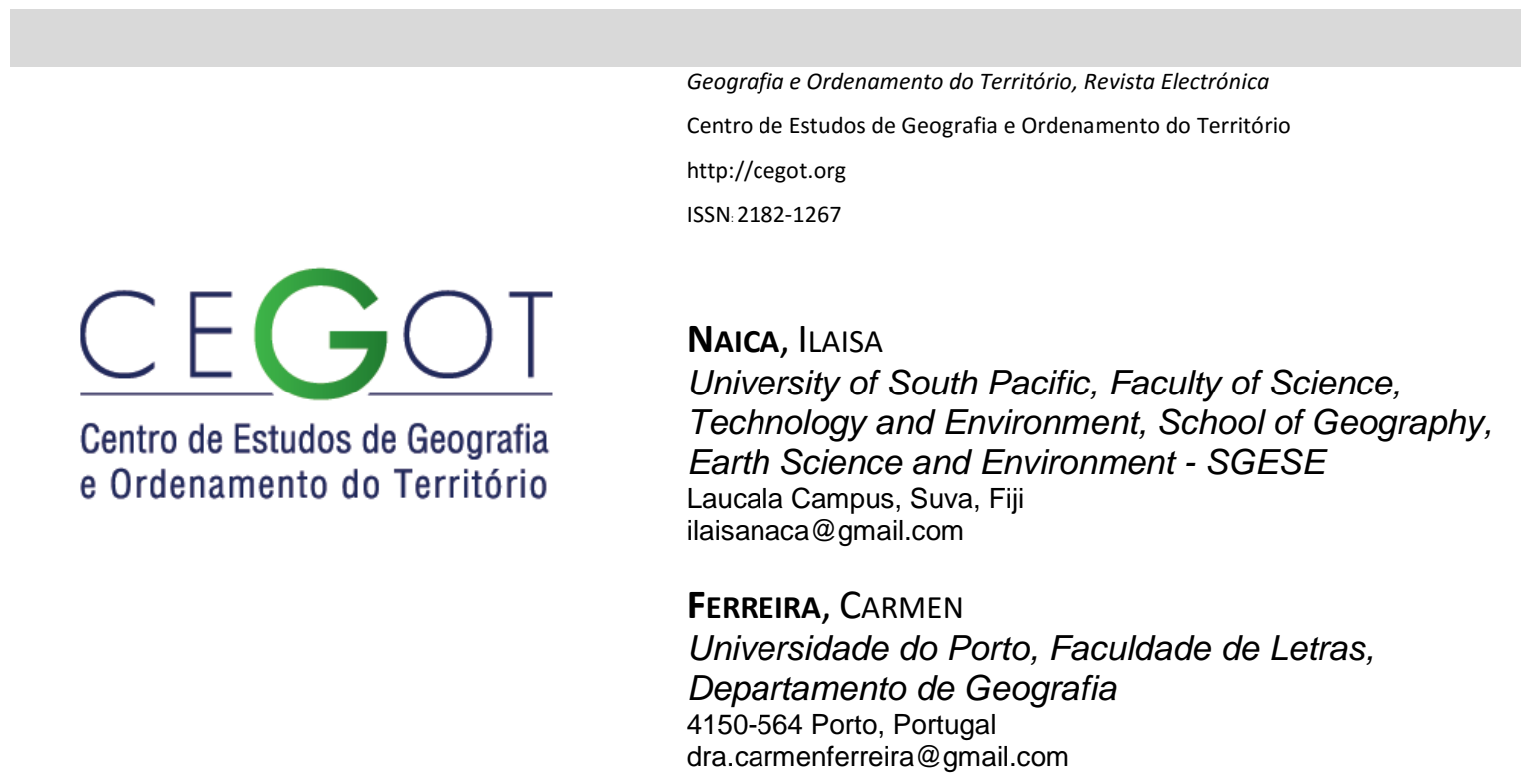

\title{
Freshwater accessibility and challenges in rural areas of Fiji: a case study of Kalabu Village
}

Os desafios da acessibilidade à água doce nas áreas rurais das Fiji: o caso de estudo da aldeia de Kalabu

Referência: Naica, Ilaisa; Ferreira, Cármen (2016). Freshwater accessibility and challenges in rural areas of Fiji: a case study of Kalabu Village. Revista de Geografia e Ordenamento do Território (GOT), n.o 9 (junho). Centro de Estudos de Geografia e Ordenamento do Território, p. 213-236, dx.doi.org/10.17127/got/2016.9.010

\begin{abstract}
Water is a key driver of economic and social development while it also has a basic function in maintaining the integrity of the natural environment. Due to its small sizes and locations of islands, many remote and rural communities in the Fiji Islands have barriers in accessing freshwater. The challenges of freshwater accessibility are not only present in small remote islands but in the two main islands of Fiji as well. Supply side solutions alone are not adequate to address the ever increasing demands from demographic, economic and climatic pressures that directly affect freshwater accessibility. Since water is a vital resource, it is important to find solutions to remove obstacles to its access. Thereby, it is imperative that accessibility issues to freshwater are not considered in isolation when you have to come to a meaningful solution to face the current challenge that will contribute to a sustainable future.
\end{abstract}

Key Words: Freshwater, Accessibility, Availability, Quality, Kalabu Village, Fiji Islands.

\section{RESUMO}

A água é o principal motor do desenvolvimento económico e social, ao mesmo tempo que tem uma função básica na manutenção da integridade do ambiente natural. Os desafios da acessibilidade à água doce em muitas comunidades rurais das Ilhas Fiji, não estão apenas 
presentes nas pequenas ilhas remotas, mas também nas duas principais ilhas da República. As soluções do lado da oferta não são adequadas para abordar as crescentes exigências das pressões demográficas, económicas e climáticas que afetam, diretamente, a acessibilidade à água doce. Sendo a água um recurso vital, é importante que se encontrem soluções para remover os obstáculos ao seu acesso. Deste modo, é imperativo que as questões de acessibilidade à água doce não sejam consideradas isoladamente quando se tem de chegar a uma solução significativa para enfrentar o desafio atual que irá contribuir para um futuro sustentável.

Palavras-chave: Água doce; acessibilidade; disponibilidade; qualidade; Aldeia de Kalabu; Ilhas Fiji.

\section{Issues and Perceptions of Freshwater Accessibility}

Reducing by one half the numbers of people in the world without access to safe drinking water is one of the key Millennium Development Goals (MDGs) (Sachs and McArthur, 2005). With an increase in population and a decrease in available freshwater resources, water scarcity has become a more and more pressing issue worldwide (Wang et al., 2010). Water resources are essential to human development processes and to achieve the MDGs that seek, inter alia, to eradicate extreme poverty and hunger, attain universal literacy, and ensure environmental sustainability (Hanjra et al., 2009). There is a growing effort to provide drinking water that has the trust of consumers, but the processes underlying the perception of drinking water quality and risks are still not fully understood (Doria Mde et al., 2009). Challenges toward achieving sustainable water supplies include a lack of recognition for the role of strong watershed management and discontinuity between policy makers, policy instrumentation, managers and scientists (Hunter et al., 2009).

Millions of people die every year around the world from diarrheal diseases much of which is caused by contaminated drinking water. By contrast, drinking water safety is largely taken for granted by many citizens of affluent nations. The ability to drink water that is delivered into households without fear of becoming ill, may be one of the key defining characteristics of developed nations in relation to the majority of the World. The report from UNED Forum, 2000, p.2, also outlines that: 
“(...) the reasons for the water crisis are not technological or financial, but are rooted in mismanagement and the inequitable allocation of resources throughout society. The political nature of some of the proposed 'solutions' to the water crisis, such as privatisation of water or biotechnology require frank public debate, with full engagement at the local level".

According to the MDG report on Water and Sanitation Targets (UNICEF \& WHO 2004); approximately 3 million people in the Oceania region do not have access to safe and adequate drinking water and sanitation services. Providing this access to improved water supplies remains a priority issue in the region. Financial, institutional and structural constraints all contribute to the inability to provide safe drinking water. Freshwater resources in small islands can be classified in two main categories that are as follows:

- Naturally occurring water resources requiring a relatively low level of technology in order to develop them. This category, which is sometimes referred to as 'conventional' water resources, includes surface water, groundwater and rainwater.

- Water resources involving a higher level of technology (sometimes referred to as "non-conventional" water resources). This category includes desalination, importation and wastewater reuse (Carpenter et al., 2003)

Hence, it is important to note that most of the Pacific Island communities rely mostly on the first category "conventional water resources" for their daily livelihoods. The Pacific Island Countries (PICs) differ significantly in size, population and resources endowment, but nevertheless share many common development constraints and challenges. PICs are constantly faced with drinking water supply problems (Mirti and Davies, 2005). Drinking water quality challenges are prevalent across the Pacific; however the degree of constraints varies from country to country. Variations in water resource availability, supply conditions, increasing pollution and water contaminants and lack of proper institutional frameworks for water quality monitoring, are all issues that affect water quality and consequently the health and well-being of Pacific Islanders.

The Fiji Islands is not an exception to this. Fiji lies in the heart of the Pacific Ocean midway between the Equator and the South Pole and between longitudes $174^{\circ}$ East and $178^{\circ}$ West of Greenwich and latitudes, between $12^{\circ}$ and $22^{\circ}$ South. Fiji's Exclusive Economic Zone 
contains approximately 330 islands of which about a third are inhabited. This covers about a 1.3 million $\mathrm{km}^{2}$ of the South Pacific Ocean (fig. 1).

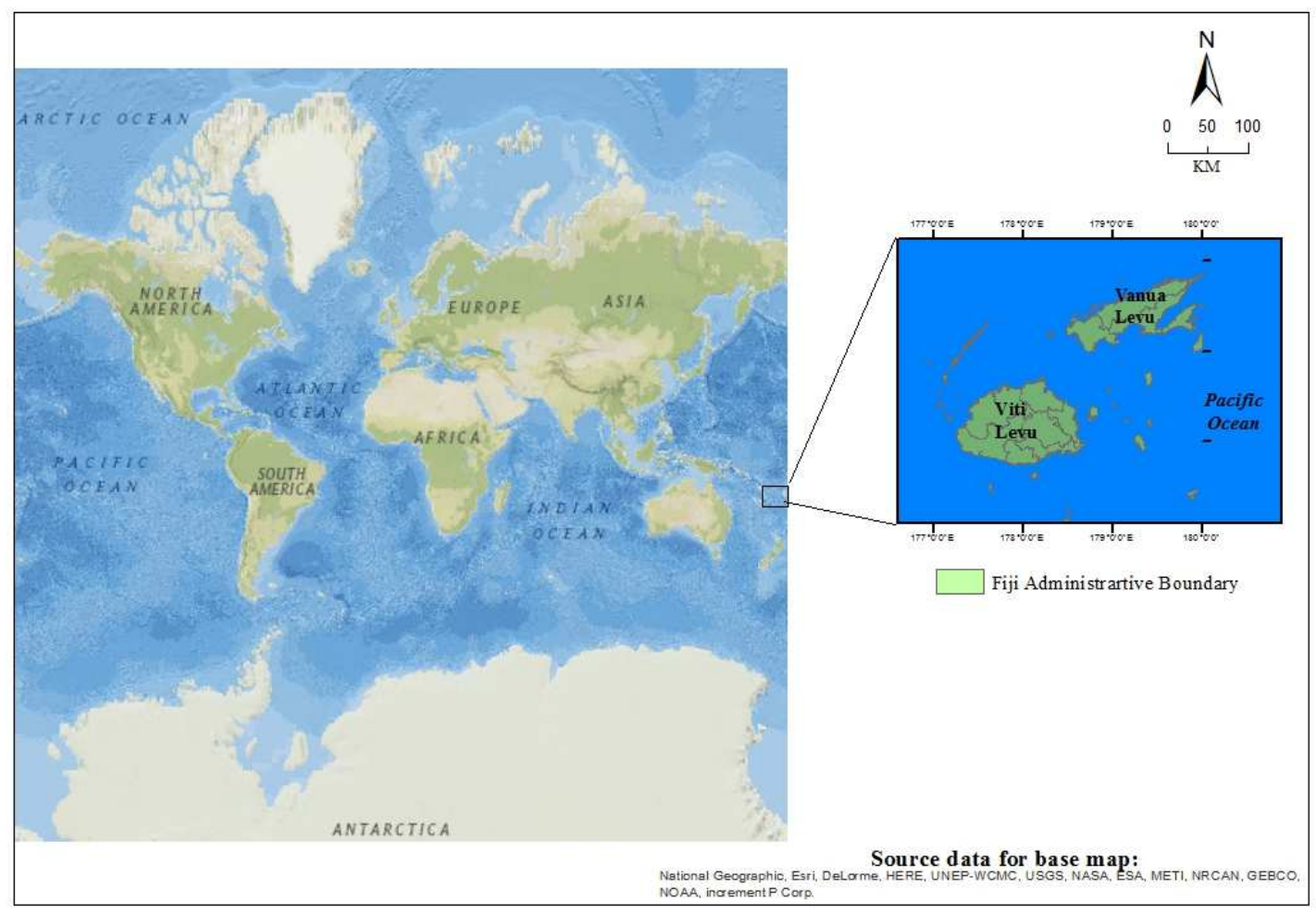

Figure 1 - Location of the Fiji Islands.

Fiji's total Land area is $18,333 \mathrm{~km}^{2}$. There are two major islands - Viti Levu which is 10,429 $\mathrm{km}^{2}$ and Vanua Levu 5,556 km². Other main islands are Taveuni $470 \mathrm{~km}^{2}$, Kadavu $411 \mathrm{~km}^{2}$, Gau $140 \mathrm{~km}^{2}$, Koro $140 \mathrm{~km}^{2}$. Most of the smaller islands are made of coral reefs and are low in elevation, thus unsuitable for habitation (Fiji Islands Bureau of Statistics, 2010).

Topographically, Fiji is divided into three major classes: plains and valleys; low mountains and hills; and high mountains. These landforms are depositional-littoral or fluvial, erosional-fluvial erosion, mass movement or volcanic. Indigenous iTaukeis own $87.9 \%$ of the land while $3.9 \%$ is State Land. Freehold land comprises of $7.9 \%$ and Rotuman land is $0.3 \%$. The capital is Suva and it is one of the two cities in Fiji. The other is Lautoka City and both are located on the island of Viti Levu where most of the population also resides. English is the official language of the country. However, iTaukei and Hindi (both languages) are also taught in schools as part of the school curriculum. 
Though in total Fiji has a large water resource, in fact these water resources are not evenly distributed - they are not equally plentiful in all places, nor is water equally available at all times. The variability is very dependent on geographical location, variability in climate conditions, and socio-economic and environmental developments (Kumar, 2010). Water accessibility challenges is experienced in almost all parts of the country but is considered to be a more occurring problem in rural areas for places such as Kalabu Village (fig. 2 ) that will be discussed more in this article.

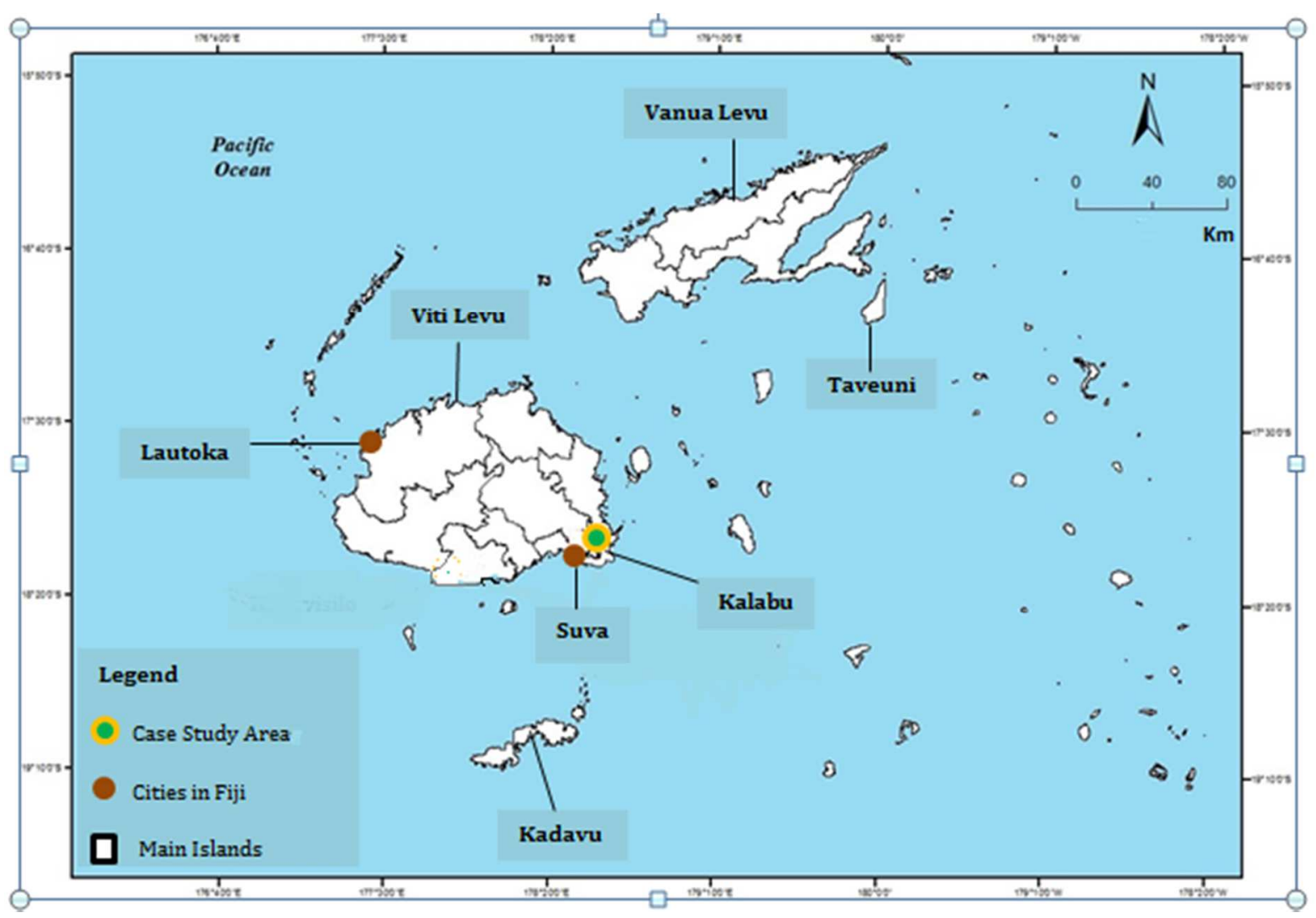

Figure 2 - Location of Kalabu Village in relation to the Fiji Islands

\section{Methodology}

As a social researcher, one cannot always collect data from everyone who is in the category being researched. Hence, there is random sampling of household to ensure that data is representative of the whole community that is being researched. Questionnaires were being distributed and observation made in the study area. Through the use of Statistical Package 
for Social Sciences (SPSS) software, twenty five (25) questionnaires from the village of thirty six household (36) are being recorded and analysed. The average household numbers range from four (4) to five (5) people per household. Presented below are the findings on issues associated with freshwater accessibility. Almost all people interviewed had been residing in Kalabu Village their whole life.

\section{Analysis and discussion of results}

As a developing country, most people in Fiji, irrespective of location, have in one way or another experience development. It was quite interesting to see the response of people based on their knowledge when it comes to changes and development that are taking place around the water sector especially when it is a basic need that affects all areas of lives (table 1).

\begin{tabular}{|c|c|c|c|c|c|}
\hline & & Frequency & Percent & Valid Percent & $\begin{array}{c}\text { Cumulative } \\
\text { Percent }\end{array}$ \\
\hline \multirow{3}{*}{ Valid } & Yes & 5 & 20.0 & 20.0 & 20.0 \\
\hline & No & 20 & 80.0 & 80.0 & 100.0 \\
\hline & Total & 25 & 100.0 & 100.0 & \\
\hline
\end{tabular}

Table 1 - People's Knowledge on Supply of Water in the Country

Do you know who controls water in Fiji?

This data reveals that only a small proportion of people know exactly who controls water supply in Fiji. For a village that owns the land where the headquarters and main supplier of water in Fiji is located, this data is quite surprising since $80 \%$ of the people who answered the questionnaire reveal they do not know who control the supply of water.

The Water Authority of Fiji (WAF) which began operation in $1^{\text {st }}$ January 2010, was established by the Government of Fiji to provide efficient and effective water and wastewater services in an environmentally sound and sustainable manner. This duty was formerly carried out by a government body known as the Water and Sewage Department (WSD). The authority is responsible for providing access to quality drinking water and waste 
water services to over 144,000 residential and non-residential metered customers reaching over 800,000 people nationwide. This includes Rotuma, rural areas and the outer islands. Nevertheless, not all areas in this location receive tap water due to certain barriers that is present to both the authority and the people.

There can be different reasons why there is a large portion of people in Kalabu do not know who controls water in Fiji and some of this can be due to:

- Less awareness and outreach made by Water Authority of Fiji and even the government to let the citizens know who controls the supply of water and the type of service provided;

- Changing of the management of water from government to private institution as in the present case for Fiji;

- People do not keep up with current affairs and recent trends of development. To some extent, there is a mindset that when it comes to decision making and authority over resources, people think it only has to do with those who are in control and have power.

The response to the question: Is water supply abundant or scarce, relating with availability of water in Kalabu village (table 2), was in favor of water being in abundance. The $28 \%$ of respondents from Kalabu village based their reasons as water being scarce due to:

- Water shortage in times of dry weather where water level in the reservoir decline

- Low water pressure at times especially in peak hours when most people are at home doing household work that are associated with water usage

- Water cuts due to pipe leakage and maintenance carried out

- Rivers being available but considered unsafe to drink due to water pollution and other reasons.

\begin{tabular}{|c|c|c|c|c|}
\hline & Frequency & Percent & Valid Percent & $\begin{array}{c}\text { Cumulative } \\
\text { Percent }\end{array}$ \\
\hline \multirow{2}{*}{ Valid Acarce } & 7 & 28.0 & 28.0 & 28.0 \\
& 18 & 72.0 & 72.0 & 100.0 \\
Total & 25 & 100.0 & 100.0 & \\
\hline
\end{tabular}

Table 2 - Availability of Water in Kalabu Village

Is water supply abundant or scarce? 
Unlike most countries where there is shortage of water supply and people do not have access to rivers and streams, Fiji is an island nation where people can easily either get to the sea, rivers, streams and can even drink from plants that store water such as Coconuts and others. In relation to other Pacific Island countries, Fiji has so many advantages when it comes to drinking water. However, there are still some communities both in urban and rural areas who do not have access to clean and safe drinking water. Due to that, a question was posed and results given in figure 3 that with respect to the many rivers in Fiji, is it possible to provide tap water to all household.

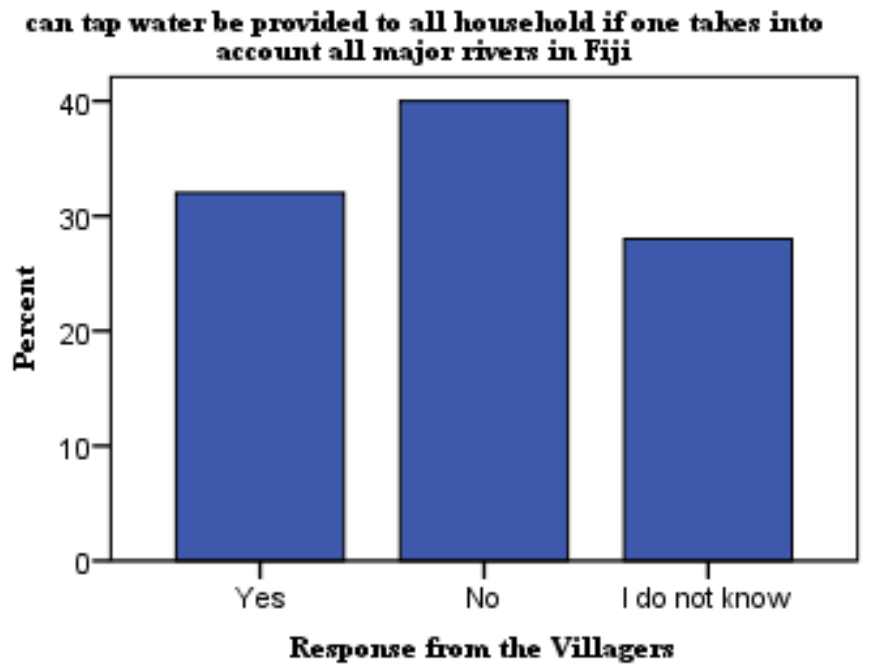

Figure 3 - Whether Tap water can be provided to all household in the country given the number of Rivers available (Kalabu Village)

Based on the responses in Figure 3, it can be noted that most of the people in Kalabu feel that tap water cannot be provided to all household in Fiji. It was pointed out by most of the respondents that one does not have to look far to get the answer to this, in most places there are rivers but the people are still without quality drinking water since creating a reservoir cost so much especially for people whose main income comes from primary and agricultural commodities.

In Kalabu, people need the river (table 3). Not only does the river supplement water in times of water shortage from the tap or even from underground water in times of drought, it provides a more meaningful purpose to the lives of people. Under the Fijian custom, rivers 
provide a form of identity to the people. It is often associated with the term "qoliqoli" (fishing ground) that separates a "mataqali" (clan) area of fishing from that of another. Also in the river, is an individual "ika" (fish) which again is another form of identity that tells more of a native Fijian when categorizing people into clans or groups.

\begin{tabular}{|ll|c|c|c|c|}
\hline & Frequency & Percent & Valid Percent & $\begin{array}{c}\text { Cumulative } \\
\text { Percent }\end{array}$ \\
\hline More than twice in a week & 7 & 28.0 & 29.2 & 29.2 \\
More than twice in a month & 4 & 16.0 & 16.7 & 45.8 \\
& I do not use the rivers at all & 4 & 16.0 & 16.7 & 62.5 \\
Valid $\quad$ Less than twice in a week & 5 & 20.0 & 20.8 & 83.3 \\
& Less than twice in a month & 1 & 4.0 & 4.2 & 87.5 \\
& Others & 3 & 12.0 & 12.5 & 100.0 \\
& Total & 24 & 96.0 & 100.0 & \\
Missing & 99.00 & 1 & 4.0 & & \\
Total & & 25 & 100.0 & & \\
\hline
\end{tabular}

Table 3 - Number of times responder use the river How often do you use the River?

While analyzing the questionnaires, it can be noted that age plays a factor when it comes to the usage of river. Most people who are over fifty (50) years of age say that they do not use the rivers at all. Unlike the older generation, the younger generation prefers to use the river more often even though they have available water in their respective household. Most of this young people use the rivers for fun and a place where they can socialise with their friends and peers. The river provided a place for "hang out" and even at times it is a place where one can get freshwater fish, prawns and other food source that is present there.

It can be seen in table 4 that there are people in Kalabu who still travel some distance in order to access freshwater. This happens mostly in times of water shortage but at times people opted to do certain activities in the river even though there is tap water for reasons such as:

- Reducing water bills and other reasons. 
- Washing clothes in bulk that is said to be easier as there is more water compared to low pressure of water from the tap.

- Giving a chance to socialize and mingle in groups while washing clothes or doing other things.

\begin{tabular}{|ll|c|c|c|c|}
\hline & Frequency & Percent & Valid Percent & $\begin{array}{c}\text { Cumulative } \\
\text { Percent }\end{array}$ \\
\hline \multirow{2}{*}{$\begin{array}{l}\text { Lalid } \quad \text { Less than half a KM } \\
\text { More than half a KM }\end{array}$} & 5 & 20.0 & 83.3 & 83.3 \\
& 1 & 4.0 & 16.7 & 100.0 \\
Motal & 6 & 24.0 & 100.0 & \\
Missing & 99.00 & 19 & 76.0 & & \\
Total & 25 & 100.0 & & \\
\hline
\end{tabular}

Table 4 - Distance traveled by villagers in Kalabu to get Water How far do you travel to get freshwater?

Since tap water is present in almost all households there is little evidence in Kalabu village as shown in table 5 to suggest an uneven distribution of freshwater. Together with this, the supply of water is controlled by an outside party; hence, there is equality in water service and very little room for biasness. Access to tap water is based on who can afford to pay both the installation and water bills that will come after every three month.

\begin{tabular}{|ll|c|c|c|c|}
\hline & Frequency & Percent & $\begin{array}{c}\text { Valid } \\
\text { Percent }\end{array}$ & $\begin{array}{c}\text { Cumulative } \\
\text { Percent }\end{array}$ \\
\hline \multirow{2}{*}{ Valid } & Nos & 1 & 4.0 & 4.2 & 4.2 \\
& Total & 24 & 92.0 & 95.8 & 100.0 \\
Missing 99.00 & 1 & 4.0 & & \\
Total & 25 & 100.0 & & \\
\hline
\end{tabular}

Table 5 - Distribution of Freshwater in Kalabu Village Is water distribution uneven in the village?

In further investigation to this matter, respondents were asked about the ownership of resources in the village (table 6), in particular land, that usually determines who owns the 
water ways. In some cases, resource owners do not allow other people from accessing any resource that is owned by them including the laying down of water pipes across their land.

\begin{tabular}{l} 
Does resource ownership prevent people from getting freshwater? \\
\hline
\end{tabular}

Table 6 - Whether Resource Ownership is a factor preventing people from accessing freshwater in Kalabu Village

Land disputes had often been contributing factor to resource being left idle without giving any returns. In Kalabu village, $5 \%$ of the respondents say that resource ownership prevents people from accessing freshwater, $64 \%$ disagrees and $4 \%$ are not familiar with such issue. In Kalabu village where water is supplied by the Water Authority of Fiji, $72 \%$ of the respondents shown in table 7 say that the main challenge is finance. While taking into account the development that is taking place near Kalabu village and its effects on water supply, only $5 \%$ of the respondents believe that pollution is a challenge.

Challenges faced with water supply

\begin{tabular}{|c|c|c|c|c|c|}
\hline & & Frequency & Percent & Valid Percent & $\begin{array}{c}\text { Cumulative } \\
\text { Percent }\end{array}$ \\
\hline \multirow{4}{*}{ Valid } & Finance & 18 & 72.0 & 72.0 & 72.0 \\
\hline & Distance & 2 & 8.0 & 8.0 & 80.0 \\
\hline & Pollution & 5 & 20.0 & 20.0 & 100.0 \\
\hline & Total & 25 & 100.0 & 100.0 & \\
\hline
\end{tabular}

Table 7 - Challenges faced by villagers at Kalabu in gaining access to Freshwater 
A common characteristic of a Fijian village is the close ties between one individual to another (table 8), the bond between families and with it the links between clans. This feature is strengthened through sharing and people helping each other.

\begin{tabular}{|c|c|c|c|c|c|}
\hline & & Frequency & Percent & Valid Percent & $\begin{array}{c}\text { Cumulative } \\
\text { Percent }\end{array}$ \\
\hline \multirow{3}{*}{ Valid } & Yes & 8 & 32.0 & 32.0 & 32.0 \\
\hline & No & 17 & 68.0 & 68.0 & 100.0 \\
\hline & Total & 25 & 100.0 & 100.0 & \\
\hline
\end{tabular}

Table 8 - Number of Household sharing water source in Kalabu village

There is interdependence and this is rooted by the core foundation of Fijian identity that is "Iotu", "vanua" and "matanitu" (religion, land and government). More than $50 \%$ of the household had their own water source. This means that more people do not share water source and is an indication of the availability of water in the area. However, the fact cannot be ignored that some household had to continue sharing water source due to financial constraints.

Like any other commodity offered through a service, there is always a price. When it comes to water bills, people often have different perception on whether there has to be a price for it or simply be classified as a free good that anyone can enjoy because it is a need and is provided by nature. Unfortunately, people had to pay a price so that they can get the service needed. In Kalabu village as given in table $9,48 \%$ of the people responded that water bills are increasing while another $48 \%$ responded that water bills is not increasing. Hence, it can be noted that there is no definite answer to actually say that water bills had actually increased or decreases because most of this household do not keep records of their water bills after it is paid. However, this question can only be answered by the Water Authority of Fiji if records of water bills paid by household over the years are analysed or even by looking at the changes in water rates set by the controlling authority over the years. 
Are water bills increasing?

\begin{tabular}{|ll|c|c|c|c|}
\hline & Frequency & Percent & Valid Percent & $\begin{array}{c}\text { Cumulative } \\
\text { Percent }\end{array}$ \\
\hline \multirow{2}{*}{ Valid } & Yes & 12 & 48.0 & 50.0 & 50.0 \\
& No & 12 & 48.0 & 50.0 & 100.0 \\
& Total & 24 & 96.0 & 100.0 & \\
Missing & 99.00 & 1 & 4.0 & & \\
Total & & 25 & 100.0 & & \\
\hline
\end{tabular}

Table 9 - Whether Water Bills is increasing in Kalabu Village

Most of the household water bills fall between the ranges of $\$ 10-\$ 90$ as shown in table 10 and figure 4. It is important to keep in mind that the average number of people in a household range from 4-5 people. These household bills tend to fluctuate at times especially when there is an occasion or function that happens in the household.

Water bills expenses

\begin{tabular}{|c|c|c|c|c|c|}
\hline & & Frequency & Percent & Valid Percent & $\begin{array}{c}\text { Cumulative } \\
\text { Percent }\end{array}$ \\
\hline \multirow{6}{*}{ Valid } & Less than $\$ 10$ & 3 & 12.0 & 12.5 & 12.5 \\
\hline & $\$ 10-\$ 20$ & 7 & 28.0 & 29.2 & 41.7 \\
\hline & $\$ 20-\$ 50$ & 6 & 24.0 & 25.0 & 66.7 \\
\hline & $\$ 50-\$ 90$ & 5 & 20.0 & 20.8 & 87.5 \\
\hline & $+\$ 100$ & 3 & 12.0 & 12.5 & 100.0 \\
\hline & Total & 24 & 96.0 & 100.0 & \\
\hline Missing & 99.00 & 1 & 4.0 & & \\
\hline Total & & 25 & 100.0 & & \\
\hline
\end{tabular}

Table 10 - Range of water bills paid by Household in Kalabu Village 


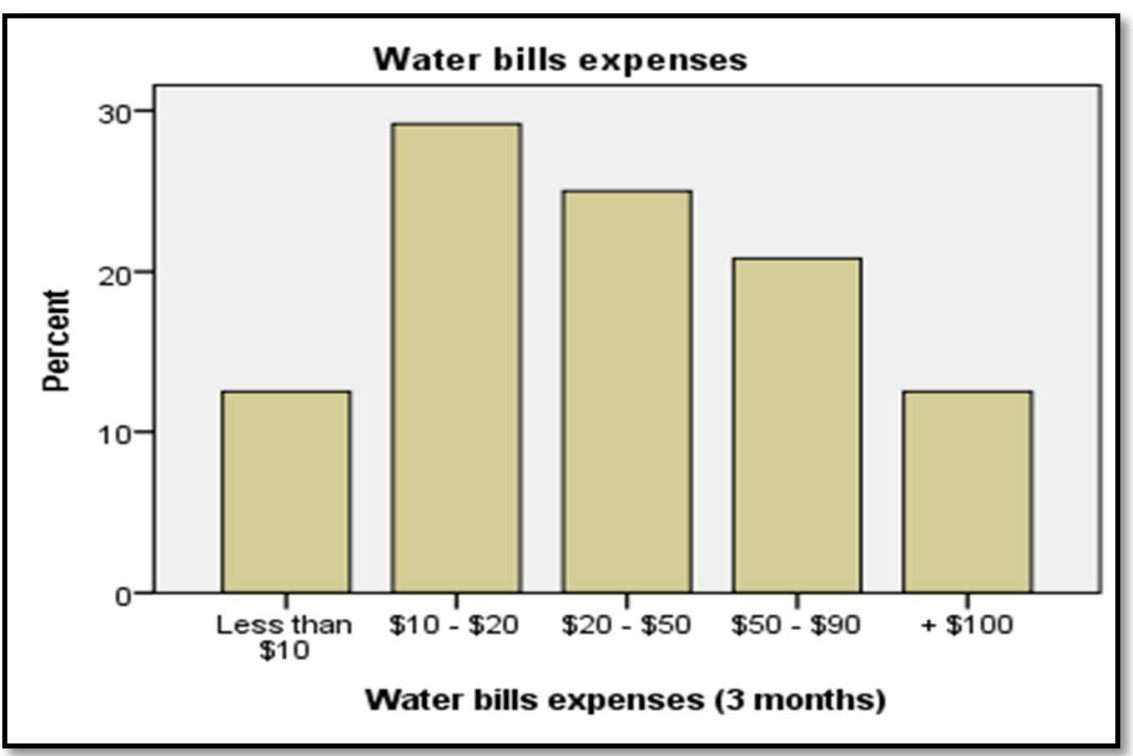

Figure 4 - Percentage range of water bills paid by household in Kalabu Village

Earlier data by the respondents reveal a mixed result where water bills is either increasing or decreasing in the case study area. In the table 11, the question was posed to household whether they are able to cope with the current water bills and interestingly, $80 \%$ of the respondents reveal that they are able to cope with the current water bills. Only $12 \%$ of the respondents reveal that they cannot cope with the water bills. However, some of the respondents reveal that sometimes water meter is being disconnected as household do not meet deadlines for payment of bills.

Are you able to cope with current water bills?

\begin{tabular}{|c|c|c|c|c|c|}
\hline & & Frequency & Percent & Valid Percent & $\begin{array}{c}\text { Cumulative } \\
\text { Percent }\end{array}$ \\
\hline \multirow{4}{*}{ Valid } & Yes & 20 & 80.0 & 83.3 & 83.3 \\
\hline & No & 3 & 12.0 & 12.5 & 95.8 \\
\hline & 3.00 & 1 & 4.0 & 4.2 & 100.0 \\
\hline & Total & 24 & 96.0 & 100.0 & \\
\hline Missing & 99.00 & 1 & 4.0 & & \\
\hline Total & & 25 & 100.0 & & \\
\hline
\end{tabular}

Table 11 - Whether Households in Kalabu Village are able to cope with their Current Water Bills 
With the high cost of leaving and low average income of most household in the village, it would be interesting to find out ways employed by people to save money. Household were asked if they have strategies and plans in place that will enable them to reduce their water bills (table 12).

Do you have strategies and plans in place to reduce water bills?

\begin{tabular}{|ll|c|c|c|c|}
\hline & Frequency & Percent & Valid Percent & $\begin{array}{c}\text { Cumulative } \\
\text { Percent }\end{array}$ \\
\hline \multirow{2}{*}{ Valid } & Yes & 13 & 52.0 & 56.5 & 56.5 \\
& No & 10 & 40.0 & 43.5 & 100.0 \\
& Total & 23 & 92.0 & 100.0 & \\
Missing & 99.00 & 2 & 8.0 & & \\
Total & & 25 & 100.0 & & \\
\hline
\end{tabular}

Table 12 - People in Kalabu village who have strategies to minimize water Bills

Thus, in Kalabu village, $52 \%$ of the respondents say that they have strategies and plans in place to help them reduce their water bills. Some of the common plans and strategies given by the respondents are as follows:

- Closing tap properly when not in use

- Using a basin to wash utensils to prevent tap from running throughout the entire period

- Repairing and maintenance of leaked pipes

- Filling buckets and bottles for drinking rather than opening the tap every now and then

- Minimizing the number of laundry times

- Using the river to wash clothes and bath for unlimited hours as it is free

There are about $40 \%$ of the respondents who mentioned that they have no strategies and plans in place to reduce water bills. Fiji has a limited number of products that is exported into the world market. One of the brands that stood out the most is "Fiji Water". Villagers were asked if they buy bottle water and $44 \%$ as shown in figure 5 of the respondents reveal that they do buy it. People have their own reason of buying bottle water but from the data gathered, it can be assumed that people who have access to tap water would prefer tap water than spending money on bottle water. 


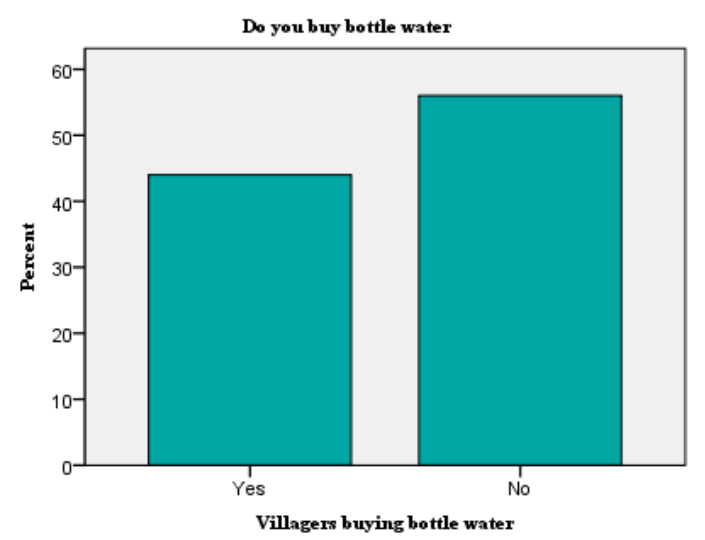

Figure 5 - Percentage of People in Kalabu who buy Bottle water.

Taking into account the location of reservoirs that is owned by the Water Authority of Fiji, it can be seen that a number of this reservoirs lies in the land owned by Kalabu village and that had been leased. There are agreements in place about this lease but there is a need to look closer into this agreement to see whether the landowners are really benefitting from the condition that is currently in place.

Majority of the respondents argues that water should not be sold at a price. Majority gave the reason that water is provided by nature and should not be sold at a price (figure 6). It is also a basic need which means that individual should have freedom of access to drinking water without any form of discrimination. Eighty-eight percent (88\%) of the respondents say that water should not have any price tag.

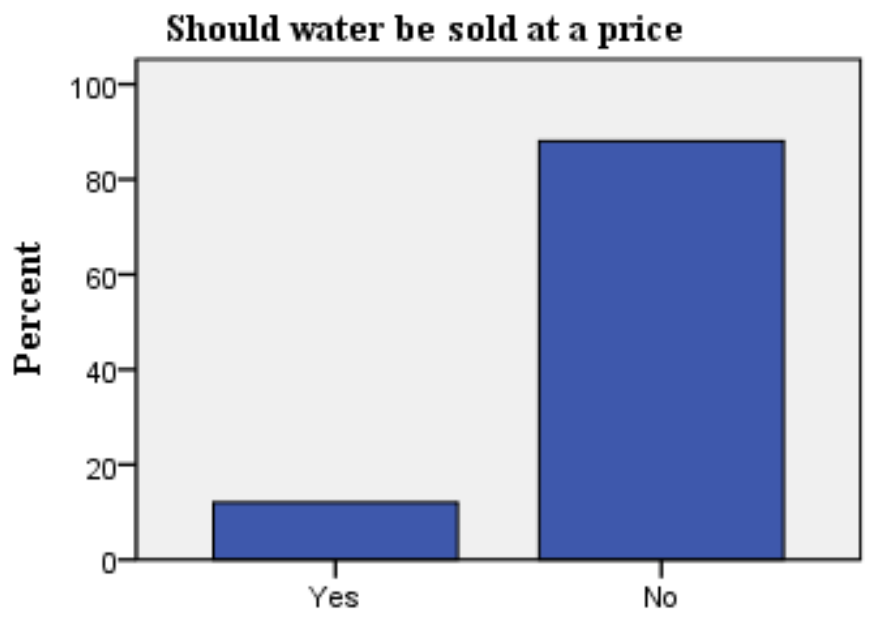

Price to be placed on water

Figure 6 - Response from Kalabu village whether water should be sold at a price 
Furthermore, climate change had been an increasing issue that has stolen discussion in most of the world gathering platform. With that in mind, effects of climate on water cannot be ignored on issues surrounding water as it is a factor that determines the supply and demand of water. Villagers in the case study area were given the question on whether climate has any influence at all in the supply of freshwater (table 13).

Does climate influence the supply of freshwater?

\begin{tabular}{|c|c|c|c|c|}
\hline & Frequency & Percent & Valid Percent & $\begin{array}{c}\text { Cumulative } \\
\text { Percent }\end{array}$ \\
\hline Yes & 20 & 80.0 & 80.0 & 80.0 \\
Valid No & 5 & 20.0 & 20.0 & 100.0 \\
& 25 & 100.0 & 100.0 & \\
\hline
\end{tabular}

Table 13 - Climate influence on Freshwater Kalabu Village

The data shows that most people believe that climate influence the supply of freshwater. Eighty percent $(80 \%)$ of the respondents implies climate to be a major determining factor in the supply of freshwater. Discussion with the villagers also shows that there had been evidence of changes in the supply of freshwater in periods of heavy rainfall and the long period of drought. Often at times of natural disasters, such as tropical cyclone and flooding, water supply is severely affected. However, people had their own coping strategies that enable them to go through things when it affects them. Since most of the household rely heavily on agriculture, their livelihood is determined by changes in climate that shapes the supply of freshwater that influence agricultural products. There is scientific evidence which suggest that there had been frequent changes in rainfall and temperature pattern not only in Kalabu but Fiji as a whole. People in the village had some fair idea regarding climate change and this is owed to education. It is usually the younger generation who understand more about changes occurring with the weather pattern and with the knowledge gained from school; they disseminate the information to their elders and family members. 
According to Sikeli Ladenona of Kalabu village "climate change is real and it affects us one way or the other".

Education plays a vital role in the dissemination of information in regards to quality drinking water (table 14). Respondents were asked whether they had attended a workshop organised in their village. More than $50 \%$ of the respondents reveal that they have attended one and this provide an indication that most of the villagers are aware of issues associated with freshwater.

Do you have organised workshop and awareness programme on water in the village?

\begin{tabular}{|c|c|c|c|c|c|}
\hline & & Frequency & Percent & Valid Percent & $\begin{array}{c}\text { Cumulative } \\
\text { Percent }\end{array}$ \\
\hline \multirow{3}{*}{ Valid } & Yes & 15 & 60.0 & 60.0 & 60.0 \\
\hline & No & 10 & 40.0 & 40.0 & 100.0 \\
\hline & Total & 25 & 100.0 & 100.0 & \\
\hline
\end{tabular}

Table 14 - Workshops and Awareness on Freshwater Issues at Kalabu Village

It can be noted in table 15 that $64 \%$ of the respondents say that they experience water problem. Population numbers had to be considered as there is thousands of household who are connected to the water main that transports water and is used by them before the water reaches Kalabu village.

\begin{tabular}{|c|c|c|c|c|c|}
\hline & & Frequency & Percent & Valid Percent & $\begin{array}{c}\text { Cumulative } \\
\text { Percent }\end{array}$ \\
\hline \multirow{3}{*}{ Valid } & Yes & 9 & 36.0 & 36.0 & 36.0 \\
\hline & No & 16 & 64.0 & 64.0 & 100.0 \\
\hline & Total & 25 & 100.0 & 100.0 & \\
\hline
\end{tabular}

Table 15 - Water Problem in Kalabu Village 
Like most problems, people have to find ways to solve it. In Kalabu village, some of the common solutions suggested by the people are:

- $\quad$ The need to have government assistance;

- Individuals to work hard and sort out the problem instead of relying on others to do things for them;

- Working together as a community and looking out for each other.

\section{Freshwater Accessibility: Weakness and Strength in the Case}

\section{Study Area}

In the study area, there is strength present that can be used as success stories when addressing issues in relation to water. Firstly, the landowners had to be commended in allowing the former and now the current water governing body to use water resources present in their land to supply water to other parts of Fiji. In return for the use of water resources and their land, the villagers receive land lease. Over the past years, there had been no history of resource conflict between the water governing bodies and the landowners. Most villages and communities in Fiji have no access to water because of land issues where landowners demand a high return from the use of their land. In some cases, even the landowners do not have safe and clean drinking water due to the fear of not being compensated if their resources are being used.

During the interview in this village, it was revealed that when the first reservoir was proposed to be built on their land, the landowners were given the option not to pay their water bills. However, this was turned down by elders in the village who strongly believed in equality and hard work that all household will pay for their water bills. Together with that, the elders wanted the people not to rely on outside parties but work hard and strive for things themselves. Indeed, with the rising issue of climate change, it is important to note that more than $80 \%$ of people are aware of the issue. This is attributed to traditional knowledge for the elders and education by the younger generation. For this reason, 
adaptation and resilience method are being accounted for in case of access water from rainfall leading to flooding or in some cases drought that will result in water shortage.

In a developing country like Fiji, location of a place will determine the type of resources that the people can access and the possible service that can be provided. Located at a higher elevation, the people in Kalabu often experience water shortage. To make the matter even worse, there are leaking pipes that needs repairing and in most occasions there is often temporary water shortage. During the investigation, the people in Kalabu village who have had a lot of experience in water shortage say that it happens during "peak hours". This is the time when almost all household tap water is switched on and as the distance grew away from the main water pipes, those household further on will not receive water until the previous households started turning off their taps. Such situation usually happen on Saturday when most people are at home doing their household work associated with water and during the morning when people rush to work, school and later on in the evening when household prepare meals and people have their bath.

Subsequently, this situation seems to be repeated every year and it seems to get even worse as the time it takes to wait for water to start running again in the tap when the other household turned their tap off becomes longer. In the same manner, even when water is running, the villages noticed that pressure seems to be low and this has also diminished over the years. This is a reason why most villagers prefer to wash clothes and do other activities associated with water in the nearby river. One does not have to be an expert in problem solving in order to see the root cause of this problem as majority of the villagers believe that population has increased over the years giving an increase in water consumption but the number of reservoirs remains the same.

Most people have very minimal knowledge about water issues at both local and national level, let alone issues affecting global water demand and supply. Studies have shown that people will only take action when they become aware of an issue. In Kalabu, one will be immensely surprised and impressed on the number of people that have access to electronic and communication devices. Almost all household have television, radio and above all, mobile phones. However, given all those devises, people have little knowledge of issues related to water. This can be proved when respondents are asked "who controls water in 
Fiji" and the response was surprising that more than half of the household in both the villagers do not know who controls water. Irrespective of location, water issues will be present in any place which means that people need to be aware on means and ways of dealing with these issues. In the same way, being knowledgeable about water related issues happening at local, national and at international level will make one realize the importance of drinking water and will influence them to conserve and sustain water even if there is abundance of it.

Water management acts and laws are not readily or easily accessible from certain locations and to certain citizens in Fiji. It is not surprising to see that few people do not wish to include the governing authority (WAF) when they need to inquire issues regarding water since they do not know the procedures and process to follow. Again, in Kalabu village where there is more development taking place, rivers and streams are adversely affected. There are legal actions that landowners and people can undertake to address this issue. However, it is sad to note that nobody is standing up for the protection of these resources simply because they thought there is no avenue to follow. The fear of going to the authority and presenting a case associated with legal jargons and processes puts people back in their comfort zone rather than standing up to the issue. Some believe that they cannot do anything about it as these are powerful organization they are dealing with. For example, the Housing Authority of Fiji (HAF) dumps excessive sewage from houses that comes under their jurisdiction into the Kalabu River causing massive environmental problem.

Freshwater accessibility is surely affected by development. The case study area as mentioned earlier in this had in one way or the other experience some form of development. A form of development that commonly exists is construction and those associated with modernization. In most cases, most development projects gets approved really fast in the village especially those that come in the form of aid. As a result, most of the development projects are cleared and given the "go ahead" sign without its implication on the environment being assessed. Industries are one that contributes a lot of adverse factors to any nearby water source. Hence, in the case of Kalabu village, this is happening as it is home to some of Fiji's large industries including the Laqere quarry, Kinoya Sewage Treatment and Power Plant, Voko industries, Garment Industries and others. The area also 
has a Tax Free Zone and to make matters worse, all this industries and factories are located few meters away from rivers and streams that later make its way to the sea. This makes one wonder if there are actually laws in place to protect the environment and for this research, water.

Whilst the discussion in the preceding chapters, water will surely become scarce if individuals continue to practice unconventional and misuse water source present around them. For most people, it has become a norm to expect that water will always be there until and when a situation struck them where there is no water then only will they appreciate the value of water to life. Apart from drinking water and household use, freshwater in the case study areas is also used in the area of agriculture, flower garden, animal husbandry and other uses. A common sight present Kalabu is that agricultural activities take place along and near the river banks. A common view is the location of toilets near the river and it is important to keep in mind that this are rural areas and they are not connected to the sewer lines that is only present in limited location around the city. Hence, there are high chances that this waste will end up in the river or even seep to underground water source. Water bills is not always constant, there is a large difference in the sum of money to be paid when a household have occasions and celebrations from the period where there is none as there is more that needs to be paid. Most of the villagers wait for the water bills to arrive on the final date and hardly anyone makes their own calculation on a timely basis (week, fortnight, month etc.) based on the meter reading in their house. There is very little investment placed on freshwater and water sector as a whole. Investing in science and technology that will further improve freshwater accessibility is a need in the case study areas since population is increasing rapidly. Given the impacts of climate change, investment in the water sector is a need for the nation. Investors prefer to invest in areas that will give them a higher return. In Kalabu village, there is a need to replace the main water pipes where household connects their water meter too as it has shown evidence of rust that had been worn out over the years.

During the survey, responders from the study areas reveal that they sometimes buy bottled water. They were then asked with the question "if water should be sold at a price" and the response from the majority was that it should not be sold at a price. Hence, they were asked 
to give their reason and most of them say that water is a need and everyone has the right to access it. Interview with the people also concluded that all water sources were once a free good but due to "greed" some people place a limit on it in order to make profit. Hence, there is limited freshwater accessibility when it comes to certain location. Private institutions tend to increase water prices in order to maximize profits and in the end, it is the consumers who bear the burden to this. A factor that is worth thinking about is that, if all resources owners decide to privatize water resources present in their land, the whole country would suffer as prices would "skyrocket" and surely some people will not have clean and safe drinking water.

To add on, another issue that does affect freshwater is climate change. Climate influence the amount of water in both artificial and natural reservoirs. Evidently, all people are affected by climate change irrespective of their location and current water source. During the dry season, villagers noted that there is usually shortage of water. There are chances that if dry season persist and continue for a long time, there are danger in most reservoirs being depleted heavily as most water source feeding the reservoir will dry out.

\section{Conclusion}

Water is a key driver of economic and social development while it also has a basic function in maintaining the integrity of the natural environment. The nature and characteristics of freshwater is such that it affects all areas of livelihood. Irrespective of geographical location, resource available and limited options that people may face, it is for sure that individuals will take any means available to satisfy their need for water.

When it comes to providing water, it is not the duty of the authority alone or the government; individuals, given the available natural resources can explore means of generating clean and safe drinking water themselves. However, this does not mean that those who are involved in decision making regarding freshwater forgo a community simply because of its isolated and rural location. These decision makers have to keep trying and pushing until accessibility to freshwater is achieved and barriers eliminated for each and 
every communities. "Grassroot" parties such as citizens themselves have to be consulted and included when it comes to dealing with barriers surrounding freshwater accessibility. Therefore, freshwater is only one of the basic needs that affect and can change the way people live without doubt. It is of utmost important that issues associated with its accessibility must not be considered in isolation. Every individual irrespective of gender, race or religion has a right to freshwater accessibility without any form of discrimination since "water is life".

\section{References}

CARPENTER, C., FALKLAND, T., OVERMARS, M. and SCOTT, D.. Pacific Dialogue on Water and Climate Synthesis Report, 2003, Suva: South Pacific Applied Geoscience Commission.

DORIA MDE, F., PIDGEON, N. and HUNTER, P. R. Perceptions of drinking water quality and risk and its effect on behaviour: a cross-national study. Sci Total Environ, 2009, 407, 5455-5464.

FIJI ISLAND BUREAU OF STATISTICS. Fiji Facts and Figures, 2010, Suva: Ratu Sukuna House.

HANJRA, M. A., FEREDE, T. and GUTTA, D. G.. Reducing poverty in sub-Saharan Africa through investments in water and other priorities. Agricultural Water Management, 2009, 96, 1062-1070.

HUNTER, P. R., ZMIROU,N. D. and HARTEMANN, P. Estimating the impact on health of poor reliability of drinking water interventions in developing countries. Sci Total Environ, 2009, 407, 2621-4.

MIRTI, V. A. and DAVIES, S. Drinking Water Quality in the Pacific Island Countries: Situation Analysis and Needs Assessment. SOPAC. 2005, Suva.

KUMAR, V. .Water Management in Fiji, International Journal of Water Resources Development, 2010, 26, 8196.

SACHS, J. D. and MCARTHUR, J. W.. The Millennium Project: a plan for meeting the Millennium Development Goals. The Lancet, 2005, 365, 347-353

UNITED NATION CHILDREN EDUCATION FUND AND WORLD HEALTH ORGANIZATION. Meeting the Millennium Development Goals on Water and Sanitation Targets: A mid-term assessment of the progress, 2004, Geneva: World Health Organization.

UNITED NATIONS ENVIRONMENT AND DEVELOPMENT. "Second World Water Forum”. In Morley, D. (ed). Perspective on Freshwater: Issues and Recommendation on NGO's. 2000, Hague. Netherlands.

WANG, H., XIE, J. and LI, H.. Water pricing with household surveys: A study of acceptability and willingness to pay in Chongqing, China. China Economic Review, 2010, 21, 136-149. 